\title{
Comparative analysis of waste-to-energy alternatives for a low-capacity power plant in Brazil
}

Waste Management \& Research

2018, Vol. 36(3) 247-258

(C) The Author(s) 2018

Reprints and permissions:

sagepub.co.uk/journalsPermissions.nav DOI: 10.1177/0734242X17751849

journals.sagepub.com/home/wmr

(SSAGE

\author{
Elzimar Tadeu de F Ferreira and José Antonio P Balestieri
}

\begin{abstract}
The Brazilian National Solid Waste Policy has been implemented with some difficulty, especially in convincing the different actors of society about the importance of conscious awareness among every citizen and businesses concerning adequate solid waste disposal and recycling. Technologies for recovering energy from municipal solid waste were considered in National Solid Waste Policy (NSWP), given that their technical and environmental viability is ensured, being the landfill biogas burning in internal combustion engines and solid waste incineration suggested options. In the present work, an analysis of current technologies and a collection of basic data on electricity generation using biogas from waste/liquid effluents is presented, as well as an assessment of the installation of a facility that harnesses biogas from waste or liquid effluents for producing electricity. Two combined cycle concepts were evaluated with capacity in the range 4-11 MW, gas turbine burning landfill biogas and an incinerator that burns solid waste hybrid cycle, and a solid waste gasification system to burn syngas in gas turbines. A comparative analysis of them demonstrated that the cycle with gasification from solid waste has proved to be technically more appealing than the hybrid cycle integrated with incineration because of its greater efficiency and considering the initially defined guidelines for electricity generation. The economic analysis does not reveal significant attractive values; however, this is not a significant penalty to the project given the fact that this is a pilot lowcapacity facility, which is intended to be constructed to demonstrate appropriate technologies of energy recovery from solid waste.
\end{abstract}

\section{Keywords}

Municipal solid waste, waste-to-energy technologies, combined cycle, gasification, incineration

Received 12th October 2017, accepted 7th December 2017 by Associate Editor Alberto Bezama.

\section{Introduction}

In Brazil, the establishment of the National Solid Waste Policy under Act Number 12,305/2010 (MMA, 2010), determines the ban on open-air dumps and landfills, which came into force from August 2014, where these must be replaced by landfills in which only waste without any possibility of recycling and reuse can be disposed.

Article 7 of Act number 12,305/2010 determines integrated management (item VII) as one of the objectives of the Brazilian policy on solid waste, as well as the adoption, development and improvement of clean technologies as a way of minimising environmental impacts (item IV). Article 9, which specifies the order of priority in management and solid waste management, assists it, namely: no generation, reduction, reuse, recycling, solid waste treatment and an environmentally correct ultimate disposal of waste.

Term 1 of article 7 of Act Number 12,305/2010 clearly states that techniques can be used for energy recovery from municipal solid waste (MSW) once their technical and environmental feasibility is ensured. In several countries, the use of energy recovery technologies is based on burning the biogas generated in landfills
(LFG, landfill gas) especially in internal combustion engines, or on incinerating solid waste; latest alternatives involve the integration of incinerators with combined cycles (hybrid cycles), as well as waste gasification.

The amount of generated MSW varies according to the Brazilian Regions, and although in 2016 the Brazilian per capita production was of $1.04 \mathrm{~kg}$ inhab day ${ }^{-1}$, Southeast Region, the most densely occupied and industrialised one, generated 104,790 $\mathrm{t}_{\text {day }}{ }^{-1}$, which means an index of $1.21 \mathrm{~kg}^{\text {inhab day }}{ }^{-1}$ (Abrelpe, 2016). The same reference estimates that 71.34 million $t y^{-1}$ are landfilled, from which 12.4 million $\mathrm{t}^{-1}$ are sent to dumps. A preliminary estimate of electricity production by incinerating

Faculdade de Engenharia de Guaratinguetá, Universidade Estadual Paulista, Guaratinguetá, SP, Brazil

\section{Corresponding author:}

José Antonio Perrella Balestieri, Universidade Estadual Paulista, Faculdade de Engenharia de Guaratinguetá, Energy Department, Avenida Dr Ariberto Pereira da Cunha 333, Guaratinguetá, SP, Brazil. Email: perrelladfeg.unesp.br 
half of the total landfilled amount represent $2.5 \mathrm{GW}$ of sustainable energy added to the Brazilian energy mix.

In order to meet this demand of electricity generation, some initiatives have been developed in Brazil in terms of energy use from LFG through research and development (R\&D) projects funded by the Brazilian Electricity Regulatory Agency (Aneel, 2012). The main results expected from this initiative are the installation of a facility for harnessing biogas from waste or liquid effluents for electricity generation with capacity exceeding $200 \mathrm{~kW}$; and an analysis of current technologies and basic data collection for electricity generation using biogas from waste/liquid effluents, including the state-of-the-art in terms of electricity generation. A third expected result is suiting and/or adapting existing technologies to the operation conditions of electric power plants using biogas from wastes/effluents located in its national territory.

The objective of the present work is to present and discuss, technically and economically, waste-to-energy cycles to be incorporated to the Brazilian electric mix. The findings of a study that was focused on accomplishing the first two previously proposed results are presented with a critical introduction of the state-ofthe-art technologies in terms of energy recovery from MSW, and for this, several configurations for a pilot low-capacity facility are conceived and compared, according to the best current technologies identified in the literature review.

\section{Methodology}

The state-of-the-art in technologies of energy recovery from MSW (waste-to-energy (WtE)) is presented herein with the aim of identifying the best available technologies and characterising the most strongly recommended ones for commercial application nowadays. The hybrid cycle that integrates solid waste incinerators with gas/steam combined is the first technology identified in the literature, taking into account that the temperature of the steam generated in the incinerator must be limited owing to corrosion problems in the thermal exchange zones. Korobitsyn et al. (1999) analysed various configurations of hybrid cycles, defining that the aggressive nature of gases released from the incinerator does not allow the steam temperature in the boiler to rise above $400{ }^{\circ} \mathrm{C}$. They also proposed that a significant increase can be achieved by the use of an external superheater and a heat recovery steam generator (HRSG) along with the gas turbine.

Qiu and Hayden (2009) assessed the feasibility of using hybrid cycles, and demonstrated that they can achieve high efficiency in energy conversion and practicality at handling MSW. In comparison with conventional MSW incineration, which achieves lower efficiency and presents operational problems, the use of a hybrid cycle considerably reduces $\mathrm{CO}_{2}$ emissions. The current practice of MSW management under the energy scenario in Thailand was analysed by Udomsri et al. (2009), in which the potential of energy recovery from MSW was researched by assessing various energy recovery technologies. Udomsri et al. (2010) has developed a study on the reduction of waste generation and application of the concept of hybrid thermal power plants, thus proving its high efficiency in comparison with the combined cycle burning natural gas, where the MSW is burned separately in an incinerating unit.

Poma et al. (2010) analysed a hybrid cycle that integrated an incinerator into the steam/gas combined cycle, designed as a possible future alternative for thermal use of municipal waste from a part of the northeastern province of Turin, Italy. It was designed to supply the local power network with $160 \mathrm{MW}$ and providing $50 \mathrm{MW}$ to a district heating network operating at full capacity. Cheng and $\mathrm{Hu}$ (2010) reported an overview of the energy recovery industry, its challenges and possible improvements in China. About $13 \%$ of the MSW generated in the country is available in energy recovery facilities, given that most facilities in operation are based on incineration units, which are considered as a mature technology if compared with other technologies with significant benefits as regards environmental quality, reduction of greenhouse gases emission, the Government's policies and funding incentives.

Ribeiro and Kimberlin (2010) proposed a combined cycle in which $80 \%$ or more of the energy was generated from MSW and the rest was supplemented with fuels that were not available in large quantities, such as landfill gas or biogas from anaerobic digestion. The difference between this concept and other existing configurations, for example Zabalgarbi, in Bilbao, Spain, is the lower consumption of natural gas, allowing $80 \%$ of the energy generated from waste to be exported, achieving efficiencies that are greater than those of the most advanced $\mathrm{WtE}$ facilities, with lower capital and operation costs.

The second technology identified for the conception of a pilot low-capacity plant is based on the MSW gasification associated to combined cycle. Bosmans et al. (2013) present a review of thermochemical technologies (incineration, gasification, pyrolysis, plasma technologies and their combinations) for energy recovery from the heating value of waste flows, focused on MSW. For some processes with emphasis on new advanced technologies, such as the plasma technology, a comparison is made between the different technologies in the context of stress factors that affect operational suitability and applicability.

Gasification offers distinct advantages over incineration: it produces a multipurpose product $\left(\mathrm{H}_{2}\right.$ and $\left.\mathrm{CH}_{4}\right)$, operates at low temperatures, it is generally more efficient than incineration and volatises fewer polluting agents than waste incineration, and it was concluded that it is a cheaper option than incineration, according to Arafat and Jijakli (2013). Fernández-González et al. (2017) confirm the economic competitiveness of MSW gasification.

Although the MSW theme is not being considered in Brazil as intensely as it is desired, since the establishment of National Solid Waste Policy (NSWP) some research is being proposed, and both technologies are under evaluation. Owing to the recent national policy on solid waste, Brazilian cities are assessing the technical and economic possibilities of non-recyclable waste incineration plants. Considering the history of solid waste deposition in São Jose dos Campos, a WtE system based on hybrid combined cycle (using MSW and natural gas) for the production of thermal and electrical energy has been proposed by Balcazar 
et al. (2013), which is attractive as regards the carbon credit and garbage fee included in the project revenues.

Maier and Oliveira (2014) evaluated the implications of the NSWP in Brazil on the economic viability of different installations of energy recovery from MSW, although the Brazilian MSW disposal market is still monopolised by landfill deposition. Given the comparative shortage of landfill regulation in Brazil and its relatively low costs as a method of disposal, plants using the energy recovery from MSW are economically unfeasible. In this way, the use of financial incentives to promote the construction of facilities of energy recovery from waste becomes vital for the investment's feasibility.

Leme et al. (2014) compared the energy generation of combustion-engine landfill-biogas and mass-burn incineration for hypothetical cities of $100,000,500,000$ and 1,000,000 inhabitants. They concluded that the second option did not present economic feasibility for the considered financial parameters adopted, mainly owing to the high cost of investment and operation/maintenance costs and low waste treatment taxes paid by the cities.

Luz et al. (2015) evaluated the technical and economic feasibility of gasification from MSW to generate electricity for the Brazilian municipalities, sorted according to population subgroups, whose parameter was used as a basis for the calculation of solid waste production, project costs and revenues. Various expenses were taken into account, such as investment, operation and maintenance costs, and interest rate variations. The revenues were estimated from the electricity and recyclable materials sale, fees paid by municipalities for MSW disposal in landfills and carbon credits. The net present value (NPV) and internal rate of return (IRR) were assessed as economic indicators. Nordi et al. (2017) demonstrated for a Brazilian city that the removal of organic matter and inert components of MSW impacted advantageously on the cycle performance, whose capacity was in the range $6-13 \mathrm{MW}$ and cost of electricity production of 60 to 150 USD MWh-1.

Based on the literature, the hybrid cycle that integrates solid waste incinerators with gas/steam combined and the MSW gasification associated to combined cycle are the technologies that best fits the composition of WtE cycles. Configurations for a pilot low-capacity plant (referred as Cases 1 to 4 in the following sections) are presented and analysed as a way to reverse the Brazilian deficit in MSW energy recovery.

\section{Technological alternatives assessment}

The project guidelines adopted in this work are according to Edict 014/2012, which states technical and commercial arrangements for insertion of electricity generation using biogas from waste and liquid effluents in the Brazilian energy mix (Aneel, 2012). Because of being a pilot, low-capacity facility, it was decided to evaluate the joint burning of LFG and MSW in the comparative analysis of technological options for harnessing biogas from waste for power generation. According to the literature, however, incineration of MSW is environmentally more attractive (Assamoi and Lawryshyn, 2012). As just a small fraction of the LFG and
MSW of the considered landfill is proposed to be burned, the conflicting concomitance of burning both fuels (once LFG originates from an anaerobic decomposition of MSW deposited in sanitary landfills) do not apply.

For modelling and simulating the configurations, the software Cycle Tempo (TU Delft, 2007) was used because it provides the necessary components for the intended conceptions. In the simulation configurations, mass and energy balances must be followed, and the exergetic efficiency of each component should be in appropriate levels. For the various addressed technologies, several parameters identified in literature were adopted so that the proposed configurations are consistent with the laws of thermodynamics, as well as constraints on energy sources availability.

- Adopted consumption of $150 \mathrm{t} \mathrm{day}^{-1}\left(1.736 \mathrm{~kg} \mathrm{~s}^{-1}\right)$ of MSW and $0.480 \mathrm{~kg} \mathrm{~s}^{-1}$ of biogas from landfill collected in Santo André, SP, a possible site in which the pilot low-capacity facility could be erected.

- The chemical composition of LFG in the city of São Bernardo do Campo, SP, and the composition of MSW collected in Santo André, SP (other compositions were also considered for a sensibility analysis) was assumed; the corresponding heating values were calculated from Mendeleev's equation and are arranged in the Table 1.

- An air condensing system was adopted owing to constraints on water availability.

For deciding on the electrical generation capacity range of the configurations to be simulated, a balance was sought between the cost of investment in equipment and the revenue resulting from selling the electricity generated by the IRR. It was considered that the IRR should be greater than $10 \%$ p.a., with simulation horizon of up to $30 \%$ p.a.; such values represent minimum and maximum annual interest rates to be considered, respectively, for an enterprise on a pilot scale. A service life of 20 years, retail electricity price of $77 \mathrm{USD} \mathrm{kWh}^{-1}$ and $7000 \mathrm{~h} \mathrm{y}^{-1}$ of WtE facility operation (values consistent with the market and the technologies' state-of-the art)

Table 1. Elemental analysis (wet basis) of LFG and MSW.

\begin{tabular}{|c|c|c|c|c|c|}
\hline \multirow{2}{*}{\multicolumn{2}{|c|}{$\frac{\text { LFG composition }}{\% \text { volumetric fraction }}$}} & \multicolumn{4}{|c|}{ MSW composition } \\
\hline & & \multicolumn{4}{|c|}{$\%$ mass fraction } \\
\hline Components & LFG & Components & MSW1 & MSW2 & MSW3 \\
\hline $\mathrm{CH}_{4}$ & 0.4769 & Carbon & 26.70 & 20.11 & 35.50 \\
\hline $\mathrm{CO}_{2}$ & 0.3739 & Hydrogen & 3.37 & 2.92 & 5.10 \\
\hline $\mathrm{H}_{2} \mathrm{~S}$ & 0.0027 & Oxygen & 16.14 & 12.58 & 23.90 \\
\hline $\mathrm{N}_{2}$ & 0.0749 & Nitrogen & 0.52 & 0.55 & 2.40 \\
\hline $\mathrm{H}_{2} \mathrm{O}$ & 0.0639 & Chlorine & - & 0.18 & - \\
\hline \multirow[t]{3}{*}{$\mathrm{O}_{2}$} & 0.0077 & Sulphur & 0.11 & 0.80 & 0.50 \\
\hline & & Moisture & 41.30 & 50.65 & 25.00 \\
\hline & & Ashes & 11.87 & 12.21 & 7.60 \\
\hline LHV $(\mathrm{kJ} / \mathrm{kg})$ & 13,804 & LHV (kJ/kg) & 9743 & 7275 & 14,112 \\
\hline
\end{tabular}

Source: LFG - personal data; MSW1 - Adapted from Nordi et al. (2014); MSW2 - Chang et al. (1998); MSW3 - Ujam and Eboh (2012). LFG: landfill gas; MSW: municipal solid waste; LHV: lower heating value. 
Cases 1-3 (Hybrid combined cycle)

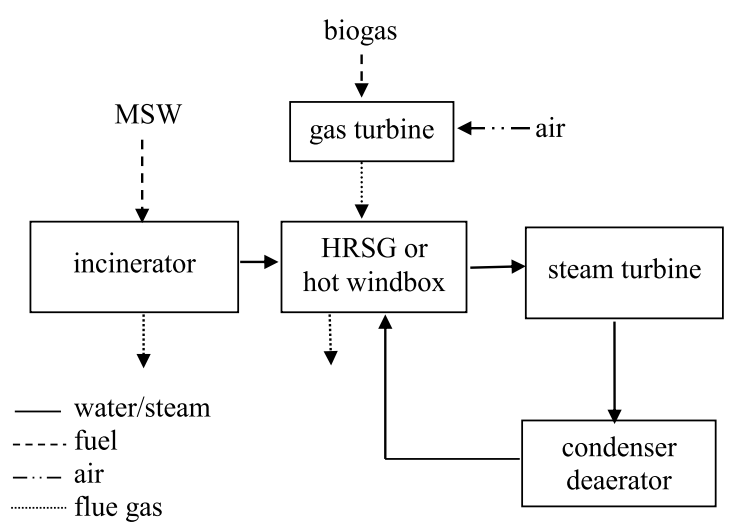

Figure 1. Conceptual schemes of proposed configurations. HRSG: Heat recovery steam generator.

was assumed, being that such values were subsequently varied in the sensitivity analysis. The investment cost of the gas turbine and condensing steam turbine was based on the equations described in Khoshgoftar Manesh et al. (2013), by simply considering that the cost of the single pressure HRSG corresponds to $11 \%$ of the gas turbine cost (Silva, 2004). Under these conditions, it was found that the capacity range of the configurations to be analysed should be in the range of 4-11 MW, given that such a range could be expanded as long as the initial parameters were changed.

From the literature review results, it was defined that the recommended technologies for designing a low-capacity pilot facility would be the integrated gasification combined cycle (IGCC, burning gasified MSW) and different conceptions of hybrid cycles (incineration of municipal waste integrated to gas turbines burning LFG or natural gas), as illustrated in Figure 1. For each of the proposed configurations, mass, energy and exergy balances were carried out by considering the technological parameters. An air excess of $100 \%$ was assumed as a parameter of the hybrid cycle incinerator project (Chang and Huang, 2001; Kranert and Cord-Landwehr, 2010; Kunz, 2009). The temperature of the exhaust gases from the incinerators air heater was set at $199{ }^{\circ} \mathrm{C}$ (Chang and Huang, 2001; Kranert and Cord-Landwehr, 2010). An isentropic efficiency of $75 \%$ was assumed for the steam turbines, which is compatible with the power generated in the four studied cases.

According to Tobiasen and Kamuk (2013), the thermal efficiency of WtE facilities that are aimed at electricity generation depends on the installation size, on the temperatures to be observed so as to avoid corrosion of the steam generator tubes, and the fact that the configuration connection occurs by cogeneration (electricity and district heating network) or only electricity generation. According to this reference, indicative values with respect to the thermal efficiency of WtE installations are $23 \%$ $26 \%$ for capacities up to $100 \mathrm{MWt}$ and higher than $30 \%$ for more than $100 \mathrm{MWt}$ when operating in the mode electricity only; for heat and power mode, values are $17 \%-23 \%$ and higher than $25 \%$, respectively. In the present analysis, reliability is not considered
Case 4 (IGCC)

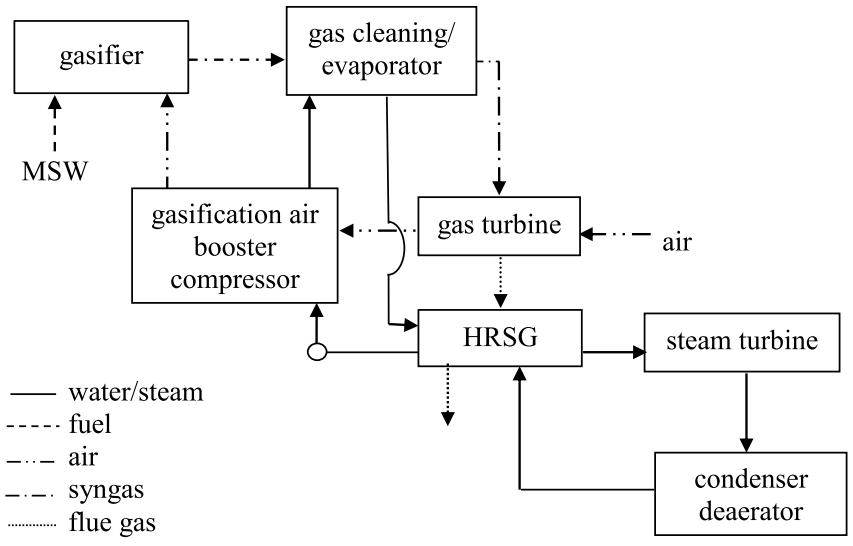

as a decision variable, although its relevance to the consecution of the project is: waste incineration is a consolidated technology if compared with waste gasification, however both present a similar availability factor, of $92 \%$ and $95 \%$, respectively, according to Wilson (2014).

Hybrid cycle: Heat recovery steam generator (Case 1). The modelled hybrid cycle consists of a Brayton cycle from a noncommercial gas turbine burning LFG; a Rankine cycle, structured by an incinerator that burns MSW and provides superheated steam at a temperature of $400{ }^{\circ} \mathrm{C}$ for a condensing steam turbine with air cooling system in the condenser. The steam temperature limit was established according to Korobitsyn et al. (1999) owing to the aggressive nature of the gases leaving the incinerator.

The preliminary parameters taken as reference for the modelling of a non-commercial gas turbine burning LFG were obtained from an Optimal Radial Turbine (http://www.opraturbines.com/ en/NEWS/) model OP16-3C, which was designed to operate with low heating value fuels, such as waste gas, syngas, biogas, coalderived gas, pyrolysis oil and ethanol. The following values apply for the gas turbine: ISO net power of $1850 \mathrm{~kW}$, heat rate of $14,827 \mathrm{~kJ} \mathrm{kWh}^{-1}$, compression ratio of 6.7 , mass flow of $8.7 \mathrm{~kg}$ $\mathrm{s}^{-1}$ and exhaust gas temperature of $573{ }^{\circ} \mathrm{C}$. Figure 2 illustrates the proposed configuration (Case 1), which resulted in a plant with $5016 \mathrm{~kW}$ of installed capacity.

Hybrid cycle: Heat exchanger for external superheating (Case 2). Korobitsyn et al. (1999) presented a configuration with external superheating named hot windbox. Such configuration offers high efficiency along with lower natural gas consumption, with smaller heat transfer area and greater thermal efficiency if compared with other hybrid cycle proposals.

In order to evaluate possible improvements in the original conception of the cycle, a hybrid model using the software CycleTempo was presented for this configuration, with LFG being used as fuel in the gas turbine and burning the MSW in the incineration boiler along its combustion process, referred to as Case 2. 


\section{Incinerator combined cycle}

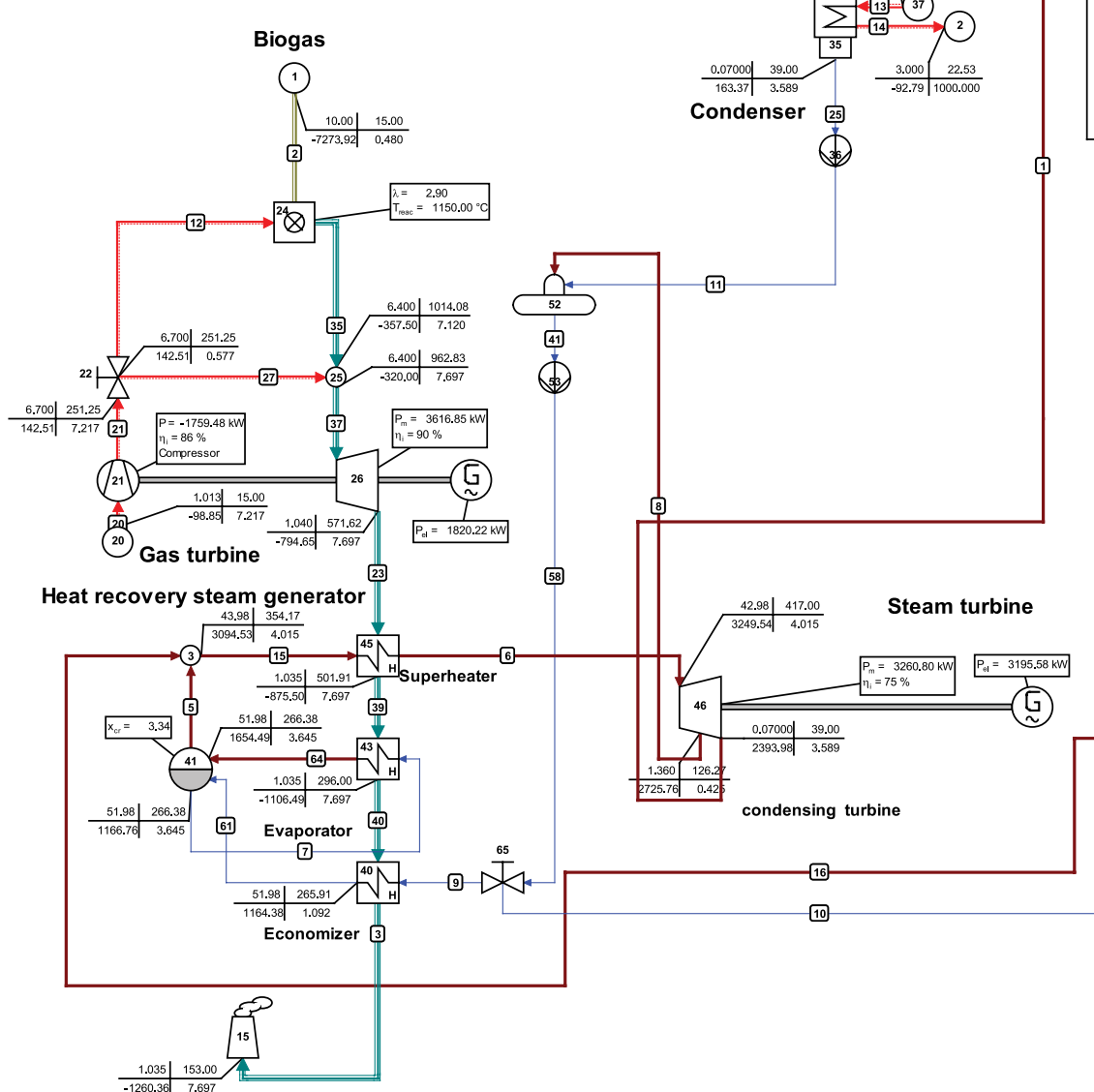

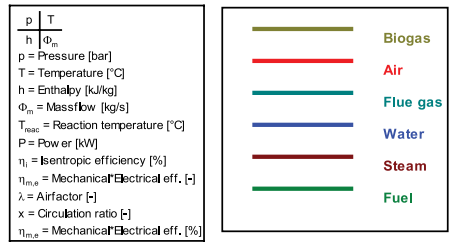

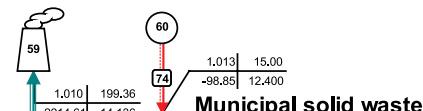

Municipal

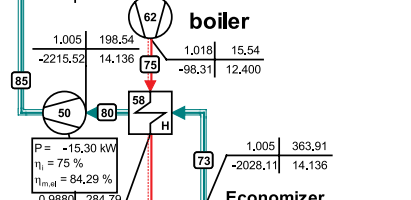

\begin{tabular}{|r|r|r|r|}
\hline 54.53 & 12.400 \\
\hline 44.98 & 104.65 \\
\hline 42.923
\end{tabular}

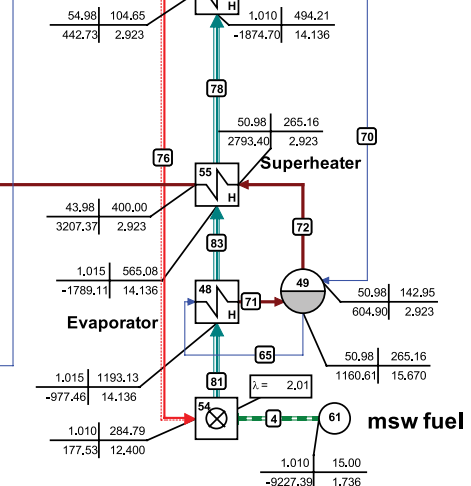

Figure 2. Case 1: Hybrid cycle, superheated steam from MSW incinerator at $400{ }^{\circ} \mathrm{C}$.

The heat recovery boiler was replaced by heat exchangers, which harness the outlet temperature of gases from the gas turbine to increase the temperature of steam to be sent to the steam turbine. Non-commercial equipment was modelled for this configuration, as shown in Figure 3.

Hybrid cycle: Heat exchanger for modified external heating (Case 3). Case 3 corresponds to the hybrid cycle in designing a hot windbox combined cycle with improvements found in literature in terms of thermal recovery of gases, including an additional heat exchanger between the condenser and the deaerator (Ghasemi, 2014; Petrov, 2003; Udomsri et al., 2011). The same conditions were simulated from previous cases, with emphasis on the fact of keeping the temperature of the steam leaving the incinerator at $400{ }^{\circ} \mathrm{C}$. However, under such conditions, the configuration did not meet the requirements of mass and energy balances, which is the reason for setting the temperature of the superheated steam leaving the incinerator at $300{ }^{\circ} \mathrm{C}$ to avoid corrosion in the sections where the superheated steam is at maximum temperature, according to studies conducted by Branchini (2012). This configuration is illustrated in Figure 4.

Integrated gasification combined cycle (Case 4). The configuration comprising an IGCC consists of a gasifier that processes
MSW to generate synthesis gas (syngas) to be burned in a gas turbine, whose preliminary parameters taken as reference for the modelling of a non-commercial unit burning syngas were obtained from the Solar Mars 100 (Solar Mars 100; http://s7d2. scene7.com/is/content/Caterpillar/C10550139). Net power generated in this case is higher than that obtained in the previous cycles, and this imposed taking another commercial gas turbine as a reference. The main reference data of such gas turbine is represented by ISO net power of $11,350 \mathrm{~kW}$, heat rate of 10,935 $\mathrm{kJ} \mathrm{kWh}^{-1}$, pressure ratio of 17.7 , mass flow of $41.6 \mathrm{~kg} \mathrm{~s}^{-1}$ and exhaust temperature of $485^{\circ} \mathrm{C}$. The thermal cycle also comprises a HRSG that harnesses the outlet temperature of gases from the gas turbine to provide thermal energy to a steam cycle with a condensing turbine, an air cooling system in the condenser and a system to remove impurities from the syngas.

According to Zafar (2009), higher capacity gasifiers are preferable to MSW treatment because they allow greater variations in fuel flow, present a uniform temperature in the process owing to the highly turbulent flow through the bed, good interaction between gases and solids and high carbon conversion rates. The author identifies the fuel capacity of $1.0 \mathrm{~kW}$ to $1.0 \mathrm{MW}$ for downdraft gasifiers, 1.1 MW to $12.0 \mathrm{MW}$ for updraft, 1.0 MW to 50.0 MW for bubbling fluidised bed and 10.0 MW to 200.0 MW for circulating fluidised bed. For the present model, a heat 


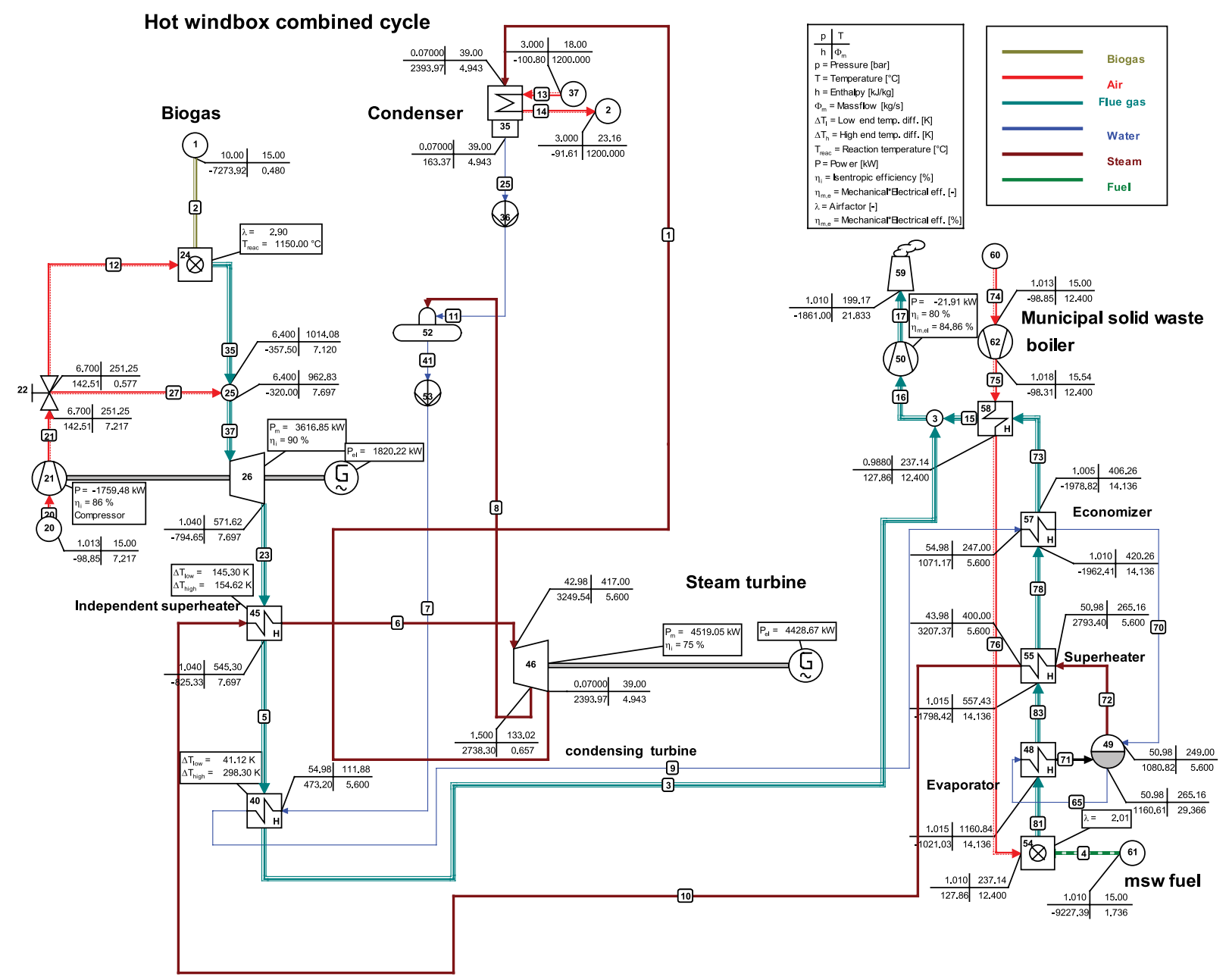

Figure 3. Case 2: Hot windbox combined cycle, steam from the MSW incinerator at $400^{\circ} \mathrm{C}$.

capacity of $16 \mathrm{MW}$ was conceived for the use of a fluidised bed gasifier.

According to Tan et al. (2015), the temperature of burning waste in an incinerator ranges from $850{ }^{\circ} \mathrm{C}$ to $1100{ }^{\circ} \mathrm{C}$, being the range of $790{ }^{\circ} \mathrm{C}$ to $1650{ }^{\circ} \mathrm{C}$ recommended for the gasification process. Zafar (2009) states that gasification processes involving a carbonaceous raw material reaction with a reagent containing oxygen, air, steam or carbon dioxide usually occur at temperatures exceeding $800{ }^{\circ} \mathrm{C}$. Thus, the gasification temperature was set at $850^{\circ} \mathrm{C}$ in this study, which is considered appropriate from an environmental point of view, since dioxins released from the MSW incineration process are destroyed and/or decomposed at temperatures above $800{ }^{\circ} \mathrm{C}$ (Sun et al., 2015).

For the technical modelling of the gasifier, a pressure of 1.4 $\mathrm{MPa}$ and an air/fuel factor of 1.60 was still considered, based on Elmegaard (1999). Figure 5 illustrates the IGCC identified as Case 4.

\section{Results and discussion}

The comparative analysis between the proposed configurations shows that the IGCC (Case 4) proved to be technically more appealing than the hybrid cycle integrated with incineration owing to the high thermal efficiency for electric generation, considering the initially defined propositions, although the incineration technology is at a more advanced stage, thus presenting a greater number of equipment vendors.

Given the fact that the MSW composition can undergo seasonal variations, it was deemed important to evaluate the variability of the technical parameters used under these conditions. For assessing the robustness of each configuration, the four cases were simulated with three different compositions of MSW (presented in Table 1), with the results of the technical assessment shown in Table 2. It should be emphasised that the configurations of hybrid cycles (Cases 1 to 3 ) are designed to burn the MSW in an incineration boiler and biogas in a gas turbine (whose composition is presented in Table 1), while the IGCC configuration (Case 4) burns the gasified MSW in a gas turbine.

The data shown in Table 2 reveal that the hybrid cycles exhibit little variability in net power capacity (for each specific Case) owing to a slight variability in the pumps' power $(0.15 \%$ to $0.22 \%$ ) and great variability in thermal efficiency (and heat rate), in which the highest value is $62 \%$ superior to the lowest one. The IGCC, in turn, presents less thermal efficiency variability (the highest value is $26 \%$ superior to the lowest one), but turns out to be quite sensitive to net power capacity variability that reached 


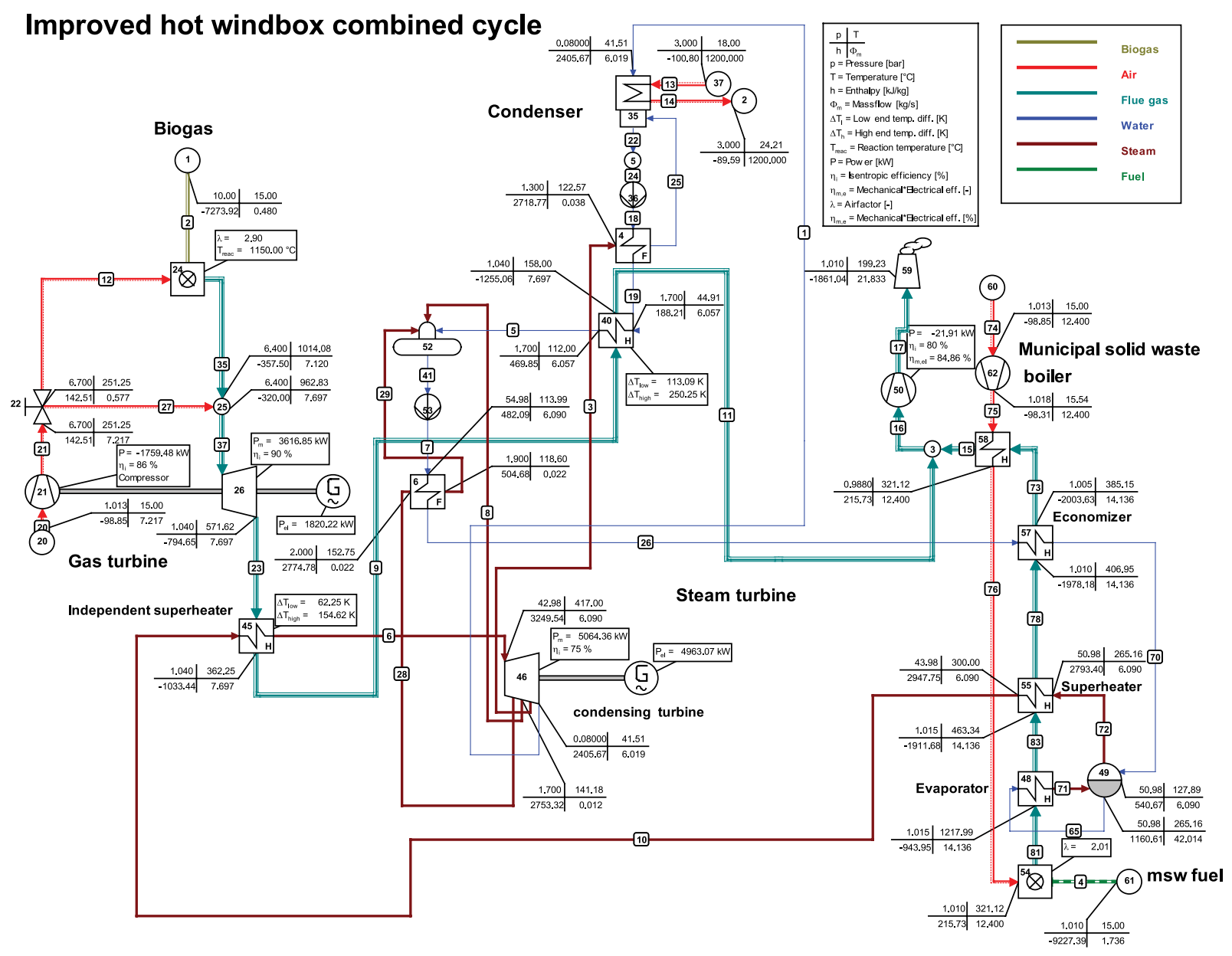

Figure 4. Case 3: Improved hot box combined cycle, steam leaving the incinerator at $300^{\circ} \mathrm{C}$.

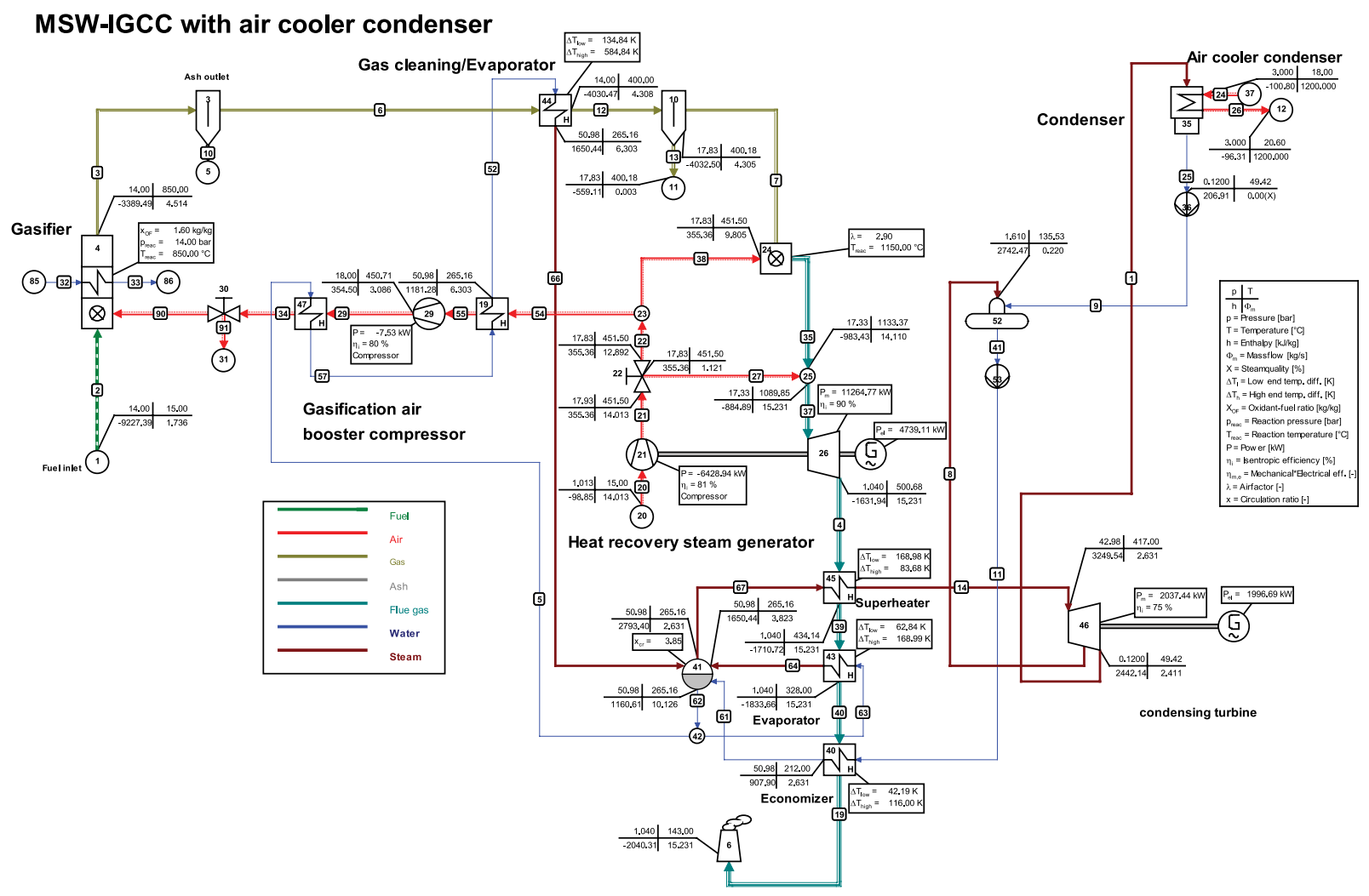

Figure 5. Case 4: IGCC. 
Table 2. Comparison between the configurations for the parameters that showed variation with MSW composition change.

\begin{tabular}{|c|c|c|c|c|c|c|c|c|c|c|c|c|}
\hline \multirow{3}{*}{$\frac{\text { Configuration }}{\text { Composition }}$} & \multicolumn{9}{|c|}{ Hybrid cycles } & \multirow{2}{*}{\multicolumn{3}{|c|}{$\frac{\text { IGCC }}{\text { Case } 4}$}} \\
\hline & \multicolumn{3}{|l|}{ Case 1} & \multicolumn{3}{|l|}{ Case 2} & \multicolumn{3}{|l|}{ Case 3} & & & \\
\hline & MSW1 & MSW2 & MSW3 & MSW1 & MSW2 & MSW3 & MSW1 & MSW2 & MSW3 & MSW1 & MSW2 & MSW3 \\
\hline$W_{\text {net }}(k W)$ & 4962 & 4966 & 4955 & 6176 & 6180 & 6169 & 6706 & 6710 & 6700 & 6708 & 4314 & 10,612 \\
\hline $\mathrm{W}_{\mathrm{ST}}(\mathrm{kW})$ & 3196 & 3196 & 3196 & 4429 & 4429 & 4429 & 4963 & 4963 & 4963 & 1997 & 1405 & 2947 \\
\hline$W_{G T}(k W)$ & 1820 & 1820 & 1820 & 1820 & 1820 & 1820 & 1820 & 1820 & 1820 & 4739 & 2931 & 7703 \\
\hline$\eta_{t}(\%)$ & 21.05 & 25.75 & 15.91 & 26.20 & 32.41 & 19.80 & 28.45 & 34.79 & 21.51 & 39.66 & 34.16 & 43.01 \\
\hline$P_{\text {exit inc }}$ (bar) & 43.98 & 43.98 & 43.98 & 43.98 & 43.98 & 43.98 & 43.98 & 43.98 & 43.98 & - & - & - \\
\hline $\mathrm{T}_{\text {exit inc }}\left({ }^{\circ} \mathrm{C}\right)$ & 400 & 400 & 400 & 400 & 400 & 400 & 300 & 300 & 300 & - & - & - \\
\hline Heat rate $\left(k J k^{-1}\right)$ & 17,151 & 14,395 & 21,697 & 13,780 & 11,568 & 17,425 & 12,690 & 10,653 & 16,047 & 9116 & 11,016 & 7873 \\
\hline$\dot{\mathrm{m}}_{\text {inlet GT }}\left(\mathrm{kg} \mathrm{s}^{-1}\right)$ & 0.48 & 0.48 & 0.48 & 0.48 & 0.48 & 0.48 & 0.48 & 0.48 & 0.48 & 4.305 & 4.287 & 4.372 \\
\hline$\dot{\mathrm{m}}_{\text {inlet ST }}\left(\mathrm{kg} \mathrm{s}^{-1}\right)$ & 4.015 & 4.015 & 4.015 & 5.600 & 5.600 & 5.600 & 6.090 & 6.090 & 6.090 & 2.631 & 1.851 & 3.883 \\
\hline
\end{tabular}

MSW: municipal solid waste.

$145 \%$. For the establishment of such variations in all cases, the difference between the lowest and highest value in each analysis divided by the parameter corresponding to MSW1 was considered.

\section{Economic assessment}

For the economic assessment of the proposed energy recovery configurations, traditional parameters are going to be calculated - NPV, IRR and payback - and the cost of power generation, according to the concept of levelised cost. The cost of investment in each technological concept will be established by equation (1) through parameters of comparison with reference installations, in accordance with Amoo and Fagbenle (2013):

$$
\mathrm{C}_{\mathrm{cp}}=\mathrm{C}_{\mathrm{cp} \mathrm{reference}}\left[\frac{\mathrm{M}_{\mathrm{MSW}_{\text {effective }}}}{\mathrm{M}_{\mathrm{MSW}_{\text {reference }}}}\right]^{0.7}
$$

in which $\mathrm{C}_{\mathrm{cp}}$ is the effective investment fixed cost; $\mathrm{C}_{\mathrm{cp} \text { reference }}$ is the reference investment fixed cost; $\mathrm{M}_{\mathrm{MSW} \text { effective }}$ is the effective installation capacity $\left(\mathrm{t}^{-1}\right) ; \mathrm{M}_{\mathrm{MSW}}$ reference is the reference installation capacity $\left(\mathrm{t} \mathrm{y}^{-1}\right)$.

For the hybrid cycles (Cases 1 to 3), it was estimated a capacity of $150 \mathrm{t}$ per day of MSW, which equals 52,500 $\mathrm{t}$ of MSW per year, assuming $8410 \mathrm{~h}$ of operation per year and the composition of MSW1, as regards a possible location for implementing the energy recovery facility. The values of fixed costs for a MSW incineration facility are $21.2\left(10^{6} \mathrm{USD}\right)$ for a reference plant size of $62,500 \mathrm{t} \mathrm{y}^{-1}$, and 41.4 (10 USD) for a reference plant size of $703,000 \mathrm{t} \mathrm{y}^{-1}$, according to Amoo and Fagbenle (2013).

In the IGCC (Case 4), the parameters of capacity and operation hours per year are assumed the same as those of the hybrid cycles. The investment cost of an installation of MSW gasification, according to Klein and Themelis (2003), is estimated to be between 86,000 and $97,000 \mathrm{USD} \mathrm{t}^{-1}$ of waste daily. For the presently studied IGCC, it was assumed an average value of 91,500 $\mathrm{USD}^{-1}$ of waste daily for the analysis development.
With these data, the cost of investment of the studied configurations can be estimated. By equation (1), the capital expenditure (CAPEX) was estimated to be at 18,764,257 USD for the hybrid cycles, where the CAPEX of IGCC was estimated at 13,725,000 USD for the location conditions of the enterprise implementation. It is necessary to consider, however, that such values can suffer significant variations. According to Greater London Authority (2008), the incineration technology investment cost is in the range 540-740 USD t $\mathrm{y}^{-1}\left(400-550 £ \mathrm{t}^{-1)}\right.$ : For example, for Case 1 with the lower heating fuel (MSW2), a CAPEX of 7530 USD kW$^{-1}$ is obtained. Yap and Nixon (2015) estimated that, in the case of England, the investment cost for gasification ranges from 620 to $850 \mathrm{USD} \mathrm{t}^{-1}$ per year: for Case 4, CAPEX varies from 3636 to $8945 \mathrm{USD} \mathrm{kW}^{-1}$ according to the lower heating value considered.

Table 3 presents the main economic parameters of each one of the four analysed cases, as well as the selling price of electricity and average electricity cost. The economic analysis presented here is based only on the simulation of each case considering the composition of MSW1, which corresponds to the actual condition of the facility to be constructed and, for the baseline scenario, which was established with $12 \%$ annual interest rate. The investment cost of Cases 2 and 3 were assumed to be $8 \%$ and $4 \%$ less than that estimated to Case 1, respectively, in face of the reduction of heat recovery area. It is observed that only Case 4 (IGCC) presents a great variation of CAPEX, owing to a significant variation of net power capacity generated with three different waste compositions, which is reflected in all economic parameters.

The levelised cost of energy (LCOE) corresponds to the cost of electricity generation produced by the thermal cycle under analysis (USD $\mathrm{MWh}^{-1}$ ). It considers the investment cost of the employed technology by the capital recovery factor (CRF) in relation to its capacity factor $(\mathrm{CF})$ of the plant, corresponding to $96 \%$ operational availability and the annual operation time (YH $\left.=8760 \mathrm{~h} \mathrm{y}^{-1}\right)$, as described in equation (2), according to Masters (2004): 


$$
\mathrm{LCOE}=\frac{\mathrm{IC} * \mathrm{CRF}}{\mathrm{YH}^{*} \mathrm{CF}}
$$

The selling price of electric energy (PEE) set by the local grid was established according to the data available (Trade Energy, 2013), corresponding to 78.18 USD $\mathrm{MWh}^{-1}$, considering the American currency exchange as $1.00 \mathrm{USD}=2.20 \mathrm{R} \$$ on that opportunity. The differences between the cost of electricity generated and the selling price of electric energy do not vary for Cases 1 to 3 for the three distinct MSW compositions, but the IGCC (Case 4) is very sensitive to this variation. The largest percentage of such a parameter is observed in Cases 1 and 4; however, as MSW composition varies in time, a mean value could be more representative for Case 4 , and the obtained value of $44 \%$ is the lowest and the most desirable one.

IRR presented in Figure 6 illustrates the variation of this economic parameter regarding the annual operation time of energy recovery facilities, ranging from 6510 to $8760 \mathrm{~h}$ a year. The return of investment (ROI or payback) is presented in Figure 7 for a desirable condition of the Brazilian economy, given that Cases 3 and 4 achieved, once again, the best results, with 5.5 y and 4 y, respectively.

As previously presented by Ferreira and Balestieri (2015), a sensitivity analysis with respect to the variability of interest rate and selling price of electricity for the network is presented for three scenarios. The optimistic scenario considered a favourable economic condition to Brazil in terms of annual interest rate (8\%) and an increase in revenue owing to cheaper electric energy selling price (100 USD $\left.\mathrm{MWh}^{-1}\right)$. The baseline case is the reference condition (12\% p.a. and $\left.78 \mathrm{USD}_{\mathrm{MWh}}^{-1}\right)$, and the pessimistic scenario is associated to the worst condition (16\% p.a. and 60 USD $\mathrm{MWh}^{-1}$ ).

Figure 8 presents the NPV as a percentage of investment capital from $70 \%$ to $130 \%$ for annual interest rates of $8 \%, 12 \%$ and $16 \%$. As is assumed by several enterprises, foreign currency covers $50 \%$ or more of the capital taken on loan of an installation of such magnitude (World Bank, 1999). Figure 9 shows the variation in LCOE for different annual operation times of the facility, ranging from 6510 the $8760 \mathrm{~h}$ per year at an annual interest rate of $8 \%, 12 \%$ and $16 \%$. In both analyses, Cases 3 and 4 maintain the best economic performance in comparison with the other alternatives.

\section{Conclusions}

Energy recovery through incineration of MSW is a wellaccepted technology in other countries than Brazil, in addition to being a rational form of environmental liability solution for that matter, thus analyses that assist in making such technology technically and economically feasible should be encouraged.

From the obtained technical results, it was found that the configuration with MSW gasification showed significantly higher levels of thermal efficiency than the analysed hybrid cycles $(43 \%$ of the 


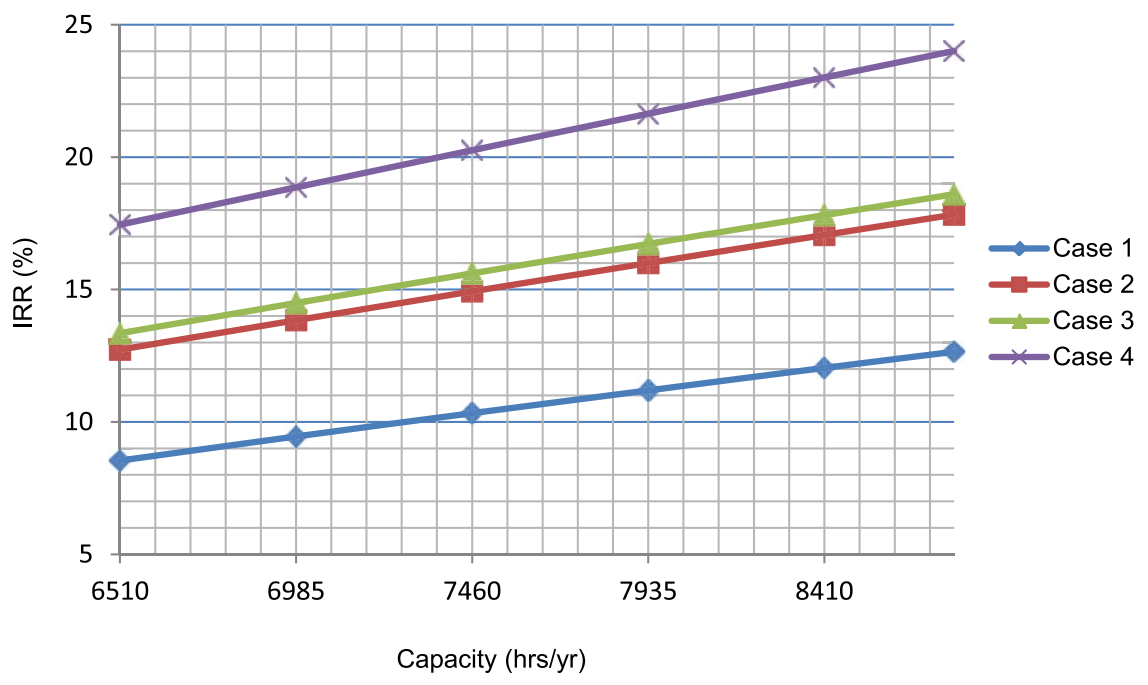

Figure 6. IRR according to capacity (installation operation time per year).

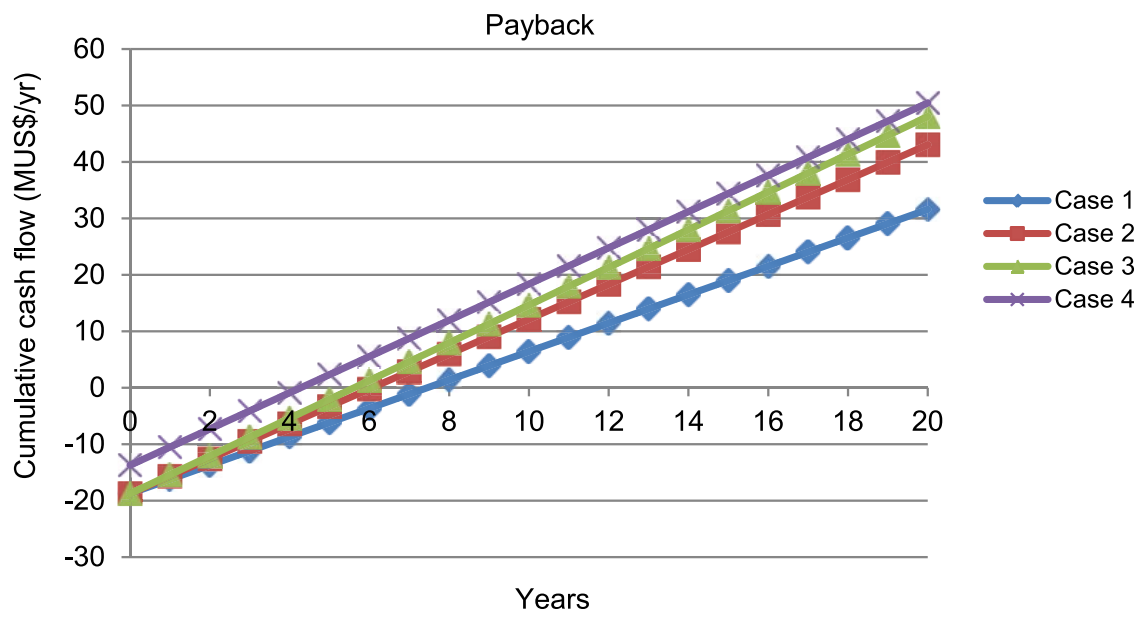

Figure 7. Payback at $12 \%$ annual interest rate.

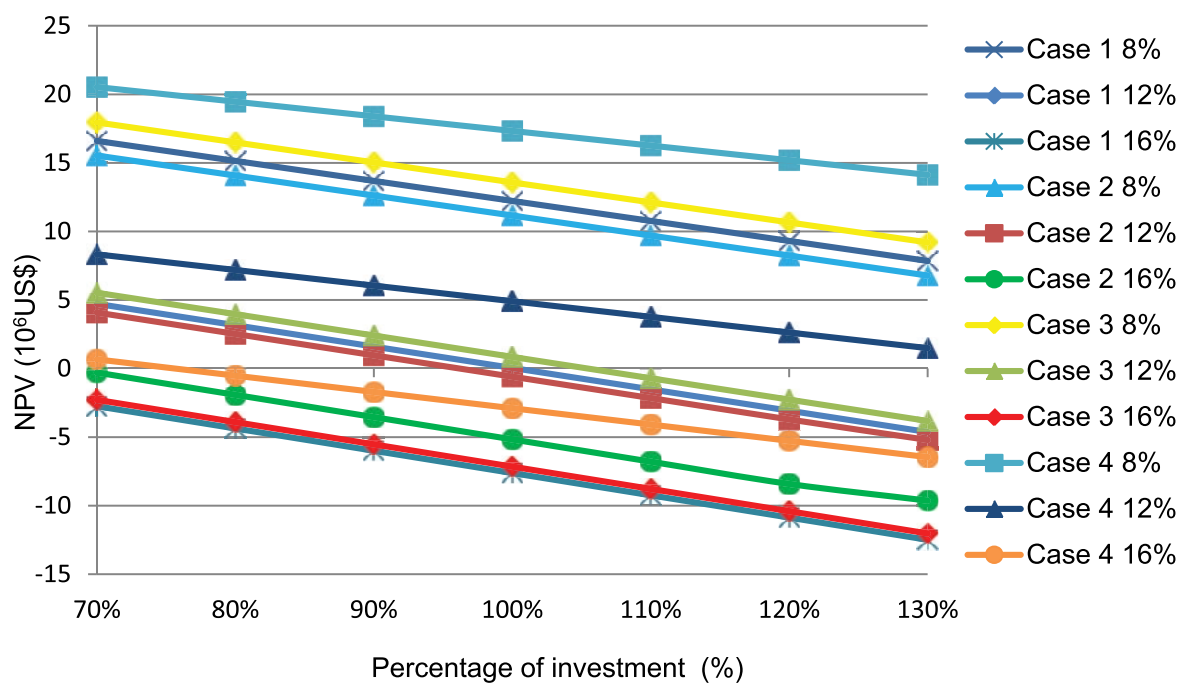

Figure 8. NPV by varying the percentage of investment capital for different annual interest rates.

IGCC against $35 \%$ of the most efficient hybrid cycle). This is partly explained by the fact that the IGCC burns syngas from gasification of MSW, while the hybrid cycle was designed with landfill biogas burning, which is concomitant with MSW incineration. 


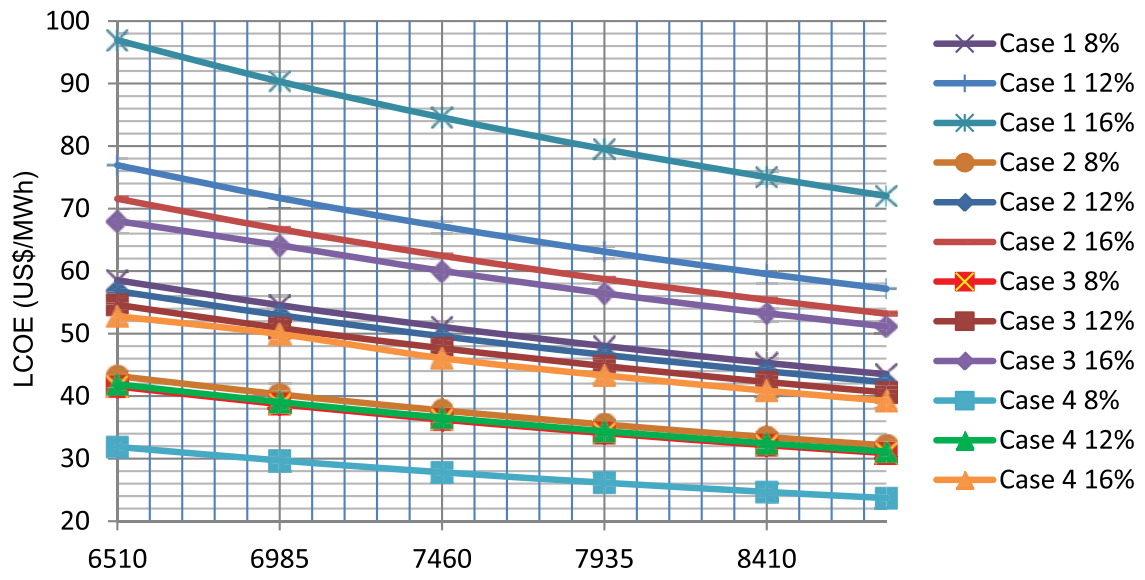

Capacity (hrs/yr)

Figure 9. Electricity cost according to capacity (yearly operation time of the installation).

Although the performed analysis was preliminary, from an economic point of view the cost of electricity of the cycle with gasification (Case 4) was revealed to be inferior to that of the hybrid cycle, with better energy conversion efficiency of MSW. A LCOE in the range 32-53 USD $\mathrm{MWh}^{-1}$ is obtained for annual interest rate of $8 \%$ and $16 \%$, respectively, for the gasification plant operating $6500 \mathrm{~h}$ per year, and these values are altered to 24-39 USD $\mathrm{MWh}^{-1}$ for the same interest rates if operating 8760 $\mathrm{h}$ per year. This study puts forward a preliminary recommendation that additional studies on MSW gasification technologies should be conducted, and that such technology must be included in future endeavours.

\section{Declaration of conflicting interests}

The authors declared no potential conflicts of interest with respect to the research, authorship, and/or publication of this article.

\section{Funding}

The authors disclosed receipt of the following financial support for the research, authorship, and/or publication of this article: Program of Research and Development of the Electricity Sector Regulated by ANEEL [process PD-0553-0022/2012] and the financial support provided by PETROBRAS, Brazil, as well as to the National Council for Scientific and Technological Development (CNPq) [process 303350/2014-8].

\section{ORCID iD}

José Antonio P Balestieri (D) https://orcid.org/0000-0003-0762-0854

\section{References}

Abrelpe (2016) Associação Brasileira de Empresas de Limpeza Pública e Resíduos Especiais [Brazilian Association of Public Cleaning and Special Waste Companies]. Overview of Solid Waste in Brazil [in Portuguese]. Available at: http://www.abrelpe.org.br/panorama_apresentacao.cfm (accessed 11 September 2017).

Amoo OM and Fagbenle RL (2013) Renewable municipal solid waste pathways for energy generation and sustainable development in the Nigerian context. International Journal of Energy and Environmental Engineering 4: 42 .
Aneel (2012) Agência Nacional de Energia Elétrica [Brazilian Electricity Regulatory Agency]. Edit $N^{\circ}$ 014/2012: Technical and commercial arrangements for the insertion of electricity generation from biogas derived from waste and wastewater in the Brazilian energy mix [in Portuguese].

Arafat HA and Jijakli K (2013) Modeling and comparative assessment of municipal solid waste gasification for energy production. Waste Management 33: 1704-1713.

Assamoi B and Lawryshyn Y (2012) The environmental comparison of landfilling vs. incineration of MSW accounting for waste diversion. Waste Management 32: 1019-1030.

Balcazar JGC, Dias RA and Balestieri JAP (2013) Analysis of hybrid wasteto-energy for medium-sized cities. Energy 55: 728-741.

Bosmans A, Vanderreydt I, Geysen D, et al. (2013) The crucial role of wasteto-energy technologies in enhanced landfill mining: A technology review. Journal of Cleaner Production 55: 10-23.

Branchini L (2012) Advanced waste-to-energy cycles. PhD Thesis, University of Bologna, pp.279. Available at: http://amsdottorato.unibo. it/4696/1/Tesi_Dottorato_Branchini.pdf (accessed 14 November 2015).

Chang MB and Huang CK (2001) Characteristics of energy flow in municipal solid waste incinerator. Journal of Environmental of Engineering 127: 78-81.

Chang Y-H, Chang N-B and Chen WC (1998) Systematic evaluation and uncertainty analysis of the refuse-derived fuel process in Taiwan. Journal of the Air \& Waste Management Association 48: 537-544.

Cheng $\mathrm{H}$ and $\mathrm{Hu}$ Y (2010) Municipal solid waste (MSW) as a renewable source of energy - current and future practices in China. Bioresource Technology 101: 3816-3824.

Elmegaard B (1999) Simulation of boiler dynamics. Available at: https:// www.etde.org/etdeweb/details_open.jsp?osti_id=20041051 (accessed 29 June 2012).

Fernández-González JM, Grindlay AL, Serrano-Bernardo F, et al. (2017) Economic and environmental review of waste-to-energy systems for municipal solid waste management in medium and small municipalities. Waste Management 67: 360-374.

Ferreira ETF and Balestieri JAP (2015) Black liquor gasification combined cycle with $\mathrm{CO}_{2}$ capture - Technical and economic analysis. Applied Thermal Engineering 75: 371-383.

Ghasemi M (2014) Parallel-powered hybrid cycle with superheating "partially" by gas turbine exhaust. PhD Thesis, Royal Institute of Technology, Sweden, pp.70. Available at: http://www.diva-portal.org/smash/get/ diva2:703366/FULLTEXT01.pdf (accessed 31March 2014).

Greater London Authority (2008) Costs of incineration and non-incineration energy from waste technologies, pp.85. Available at: http://legacy.london.gov.uk/mayor/environment/waste/docs/efwtechnologiesreport.pdf (accessed 12 January 2016).

Khoshgoftar Manesh MH, Navid P, Blanco Marigorta AM, et al. (2013) New procedure for optimal design and evaluation of cogeneration system 
based on advanced exergoeconomic and exergoenvironmental analyses. Energy 59: 314-333.

Klein A and Themelis N (2003) Energy recovery from municipal solid wastes by gasification, pp.50. Available at: http://www.researchgate.net/profile/Nickolas_Themelis/publication/255585595_ Energy_Recovery_from_Municipal_Solid_Wastes_by_Gasification/ links/00b7d5395fd92d0a74000000.pdf (accessed 1 December 2015).

Korobitsyn MA, Jellema P and Hirs GG (1999) Possibilities for gas turbine and waste incinerator integration. Energy 24: 783-793.

Kranert M and Cord-Landwehr K (2010) Einführung in die abfallwirtschaft, 4 Auflage. Vieweg+Teubner Verlag Springer Fachmedien Wiesbaden GmbH.

Kunz RG (2009) Environmental Calculations - A Multimedia Approach. Wiley.

Leme MMV, Rocha MH, Lora EES, et al. (2014) Techno-economic analysis and environmental impact assessment of energy recovery from municipal solid waste (MSW) in Brazil. Resources, Conservation and Recycling 87: $8-20$.

Luz FC, Rocha MH, Lora EES, et al. (2015) Techno-economic analysis of municipal solid waste gasification for electricity generation in Brazil. Energy Conversion and Management 103: 321-337.

Maier S and Oliveira LB (2014) Economic feasibility of energy recovery from solid waste in the light of Brazil's waste policy: The case of Rio de Janeiro. Renewable and Sustainable Energy Reviews 35: 484-498.

Masters GM (2004). Renewable and efficient electric power systems. New Jersey, USA: John Wiley.

MMA (2010) Brazilian Ministry of the Environment. Act number 12,305: National Policy of Solid Wastes. Available at: http://www.mma.gov.br/ port/conama/legiabre.cfm?codlegi=636 (accessed 1 August 2012).

Nordi GH, Palacios-Bereche R, Gallego AG, et al. (2014) Energetic analysis of electricity production in Rankine cycles from municipal solid waste in Brazil, pp.15. Available at: http://sw-indo.com/energetic-analysis-ofelectricity-production-in-rankine-cycles-from-municipal-solid-waste-inbrazil/ (accessed 13 June 2015).

Nordi GH, Palacios-Bereche R, Gallego AG, et al. (2017) Electricity production from municipal solid waste in Brazil. Waste Management \& Research 35: 709-720.

Petrov MP (2003) Biomass and natural gas hybrid combined cycles. Licentiate Thesis, Royal Institute of Technology, Sweden, pp.100. Available at: http://www.diva-portal.org/smash/get/diva2:7598/FULLTEXT01.pdf (accessed 30 March 2014).

Poma C, Verda V and Consonni S (2010) Design and performance evaluation of a waste-to-energy plant integrated with a combined cycle. Energy 35: 786-793.

Qiu K and Hayden ACS (2009) Performance analysis and modeling of energy from waste combined cycles. Applied Thermal Engineering 29: 30493055.

Ribeiro SG and Kimberlin T (2010) High efficiency waste to energy power plants combining municipal solid waste and natural gas or ethanol, pp.7. Available at: http://www.wtert.com.br/home2010/arquivo/publicacoes/ paper_nawtec18-ciclo_combinado_otimizado-solucao_ideal_para_o_ lixo brasileiro.pdf (accessed 2 May 2014).

Silva MM (2004) Repowering of power generating system in steel mill sector by using thermoeconomic analysis [in Portuguese]. PhD Thesis, Faculty of Mechanical Engineering, UNICAMP, Campinas.

Sun R, Ismail TM, Ren X, et al. (2015) Numerical simulation of gas concentration and dioxin formation for MSW combustion in a fixed bed. Journal of Environmental Management 157: 111-117.

Tan ST, Ho WS, Hashim H, et al. (2015) Energy, economic and environmental (3E) analysis of waste-to-energy (WTE) strategies for municipal solid waste (MSW) management in Malaysia. Energy Conversion and Management 102: 111-120.

Tobiasen L and Kamuk B (2013) Waste to energy (WTE) systems for district heating. In: Klinghoffer NB and Castaldi M J (Eds) Waste to Energy Conversion Technology. Cambridge, UK: Woodhead Publishing Limited, pp.120-145.

Trade Energy (2013) Prices of electricity. Available at: http://www.tradeenergy.com.br/comunicacao-imprensa.php (accessed 8 November 2013).

TU Delft, Cycle-Tempo version 5.0 (Build 481) Copyright 1980-2007. Delft University of Technology.

Udomsri S, Martin AR and Fransson TH (2009) Municipal solid waste management and waste to energy alternatives in Thailand, pp.8. Available at: http://inpact.inp-toulouse.fr/archives/WasteEng05/FullText_C/198_seksan_05_02_09.pdf (accessed 11 May 2014).

Udomsri S, Martin AR and Fransson TH (2010) Economic assessment and energy model scenarios of municipal solid waste incineration and gas turbine hybrid dual-fueled cycles in Thailand. Waste Management 30: 1414-1422.

Udomsri S, Petrov MP, Martin AR, et al. (2011) Clean energy conversion from municipal solid waste and climate change mitigation in Thailand Waste management and thermodynamic evaluation. Energy for Sustainable Development 15: 355-364.

Ujam AJ and Eboh F (2012) Flue gas analysis of a small-scale municipal solid waste-fired generator. International Journal of Computational Engineering Research 2: 8-20.

Wilson B (2014) Comparative assessment of gasification and incineration in integrated waste management. EnviroPower Renewable Report, Boca Raton, FL. Available at: http://www.eprenewable.com/uploads/ files/63 5 Gasification White Paper_10-08-2014.pdf (accessed 8 August 2016).

World Bank (1999) Municipal solid waste incineration: Technical Guidance Report. Washington, DC: Clearance Center, pp.111. Available at: http:// web.mit.edu/urbanupgrading/urbanenvironment/resources/references/ pdfs/MunicipalSWIncin.pdf (accessed 10 January 2018)

Yap HY and Nixon JD (2015) A multi-criteria analysis of options for energy recovery from municipal solid waste in India and the UK. Waste Management 46: 265-277.

Zafar S (2009) Gasification of municipal solid wastes. Energy Manager 2: $47-51$. 